\title{
The effect of lumen conditions on oxygen uptake in perfused omasal laminae
}

\author{
BY F. J. LOZEMAN* AND L. P. MILLIGAN \\ Department of Animal Science, University of Alberta, Edmonton, Canada T6G 2P5
}

(Received 11 May 1984 - Accepted 24 September 1984)

1. The vascular anatomy of the bovine omasal lamina permitted perfusion of a discrete area of the tissue. As occurs in vivo, oxygen was provided through the vascular system, while the luminal sides of the tissue could be kept in an anaerobic environment, thus allowing study of foregut tissue metabolism under physiologically realistic conditions.

2. $\mathrm{O}_{2}$ consumption of perfused leaves in the presence of anaerobic buffer was 64.9 and $73 \cdot 5 \mathrm{nmol} \mathrm{O} / \mathrm{mg} \mathrm{dry}$ weight per $\mathrm{h}$ in Expts 1 and 2 respectively, and was elevated $(P<0.05)$ when the lumen side of the tissue was exposed to an atmosphere of nitrogen gas.

3. In Expt 1 , the rate of $\mathrm{O}_{2}$ consumption was increased $(P<0.01)$ by $35 \%$ as a result of suspension of a boiled preparation of rumen micro-organisms and particles $(<1 \mathrm{~mm})$ in the anaerobic lumen buffer. Replacement of the boiled preparation with an unboiled suspension increased $\mathrm{O}_{2}$ consumption further by $11 \%$, but this was not statistically significant $(P>0.05)$.

4. In Expt 2, sequential addition of the following substrates or preparations to the lumen chambers all resulted in stepwise increases $(P<0.05)$ in $\mathrm{O}_{2}$ consumption; 8 mm-butyrate, boiled rumen micro-organisms and particles and, finally, unboiled rumen micro-organisms and particles.

5. Identities of the heat-labile and heat-stable components of the microbial and particle suspensions that caused enhancement of $\mathrm{O}_{2}$ removal across the perfused tissue are discussed.

The epithelium of the ruminant forestomach forms the interface between the blood and the pregastric environment in which micro-organisms ferment available feedstuffs. It has traditionally been accepted that the lumen of the forestomach is largely devoid of oxygen (Hungate, 1966). However, Czerkawski (1969) reasoned that the volume of blood delivered to the reticulo-rumen was far greater than would be anticipated considering the mass and the nature of the tissues, and he calculated that as much as 38 litres $\mathrm{O}_{2} / \mathrm{d}$ could diffuse into the lumen of the reticulo-rumen. Recent isolation of bacteria from the epithelium of the rumen has indicated that $25-50 \%$ of the adherent population of bacteria are facultative anaerobes (Cheng \& Costerton, 1980). It was suggested that these bacteria are able to utilize $\mathrm{O}_{2}$ derived from the rumen wall during oxidation of reduced products of fermentation and thereby protect $\mathrm{O}_{2}$-intolerant rumen micro-organisms from exposure to $\mathrm{O}_{2}$ that might enter the rumen from the wall.

The present studies were undertaken to measure $\mathrm{O}_{2}$ uptake by perfused omasal leaf as an example of the ruminant forestomach wall, and to establish if this $\mathrm{O}_{2}$ uptake was responsive to conditions on the lumen side of the tissue.

\section{MATERIALS AND METHODS \\ Collection of omasal tissue}

Omasal tissue was collected at a local abattoir 12 min after the death of steers and heifers $(400-650 \mathrm{~kg})$ which had been given a mixed grain-roughage diet. The omasum was cut in half, parallel to the attachment of the laminae to the convex edge, and a full-sized leaf was chosen and placed in 1 litre 75 mm-sodium chloride- $75 \mathrm{~mm}$-Tris (hydroxymethyl)

\footnotetext{
* Present address: Department of Biochemistry, University of Oxford, South Parks Road, Oxford OX1 3QU.
} 
aminomethane buffer, $\mathrm{pH} 7 \cdot 4$. The temperature of the solution was maintained at $18 \pm 2^{\circ}$ for transport of the tissue to the laboratory. Lower transport solution temperatures resulted in collapsed and indistinguishable blood vessels. Successful catheterization was dependent on rigid and dilated arteries, therefore nitroglycerin (Parke Davis, Edmonton, Alberta) was included $(0.06 \mathrm{mg} / \mathrm{l})$ in the transport buffer.

\section{Catheterization}

Several characteristics of the vascular anatomy of the omasal laminae contributed to the ease and effectiveness of perfusion of this tissue. First, veins which return blood to the surface of the omasum are generally satellites of the arteries (Comline et al 1968). Therefore, at the point where the leaf had been severed from the omasum, arteries descending into the leaf were immediately adjacent to the vein which drained the same area of tissue. In addition, radial branches of the descending arteries anastomose and form a network of vessels which provide several points of supply to the subepithelial capillary bed (Comline et al. 1968) enabling the supply of $\mathrm{O}_{2}$ to an isolated area of tissue by perfusion through one artery.

On reaching the laboratory, the tissue was rinsed with $0.15 \mathrm{M}-\mathrm{NaCl}\left(38^{\circ}\right)$ to remove adhering digesta. A dissecting microscope was centred above an artery-vein couple about 0.25 of the distance along the convex edge of the leaf from the abomasal to the reticular end. The leaf was separated by pulling apart the mucosal sides from the cut edge to reveal a $10 \mathrm{~mm}$ length of exposed artery and vein; the artery and the vein remained together when the tissue was split. A carefully-ground and rounded stainless-steel capillary tube $(0.15 \mathrm{~mm}$ i.d., $0.30 \mathrm{~mm}$ o.d.; Small Parts Inc., Miami, FL) was inserted into the lumen of the artery and pushed down the vessel until the end of the tube was resting beyond the section of artery that had been exposed by separation of the tissue. Before insertion, the tube had been connected to a $350 \mathrm{~mm}$ length of polyvinyl chloride micro-bore tubing $(0.25 \mathrm{~mm}$ i.d., $0.76 \mathrm{~mm}$ o.d.; Cole Palmer Ltd., Chicago, IL). The arterial catheter was immediately flushed with heparinized $0 \cdot 15 \mathrm{M}-\mathrm{NaCl}\left(38^{\circ}\right)$ until there was effluent from the adjacent vein. The vein was catheterized in a similar manner with a stainless-steel tube $(0.58 \mathrm{~mm}$ i.d., $0.89 \mathrm{~mm}$ o.d.) which was connected to polyvinyl chloride tubing $(0.51 \mathrm{~mm}$ i.d., $0.89 \mathrm{~mm}$ o.d.). The catheters were secured to the tissue by a single suture around both stainless-steel tubes. Subsequent flushing with heparinized $0 \cdot 15 \mathrm{M}-\mathrm{NaCl}\left(38^{\circ}\right)$ allowed an assessment of the catheterization. If flow through the tissue and out of the venous catheter could not be established or if excessive leaking occurred, catheterization was initiated at another artery-vein couple.

\section{Perfusion chamber mounting of the tissue}

The chamber designed for perfusion of omasal laminae was modelled on that described by Hird \& Weidemann (1964). It consisted of two rectangular $125 \times 100 \times 25 \mathrm{~mm}$ acrylic plastic halves. Each half had a $37 \mathrm{~mm}$ diameter $\times 7 \mathrm{~mm}$ deep cylindrical hollow (lumen compartment) milled into it with two 2-mm diameter ports through the top to the hollow, a $3.5 \mathrm{~mm}$ groove down the centre of the half (and through the ' $O$ ' rings) to allow access of the perfusion catheters to the tissue and a groove to hold one of the two concentric rubber ' $O$ ' rings $(71 \mathrm{~mm}$ and $41 \mathrm{~mm}$ i.d.) that sealed the assembled system. When clamped together with the tissue between the two halves, the ' $O$ ' rings crimped and sealed the tissue such that the area that was perfused was that within the smaller ring.

Once the tissue was catheterized, it was positioned on the base of the perfusion chamber so that the embedded ends of the arterial and venous catheters were just protruding into the lumen compartment and the catheterized artery-vein couple was centred down the middle of the lumen compartment. The arterial and venous catheters were set into the catheter groove and the two halves of the chamber were then clamped together. In order 
Table 1. Perfusion and lumen chamber media

\begin{tabular}{llc}
\hline \hline & $\begin{array}{c}\text { Final } \\
\text { concentration } \\
\text { (mM) }\end{array}$ \\
\hline & Sodium chloride & $108 \cdot 0$ \\
& Potassium chloride & $4 \cdot 7$ \\
Calcium chloride & $3 \cdot 0$ \\
Magnesium sulphate & $1 \cdot 2$ \\
Potassium phosphate, monobasic & $1 \cdot 2$ \\
Ethylenediamine tetraacetic acid, & $0 \cdot 5$ \\
disodium salt & $25 \cdot 0$ \\
Hepes* & $10 \cdot 0$ \\
Sodium bicarbonate & $1 \cdot 2 \mu \mathrm{g} / 1$ \\
Nitroglycerin $\dagger$ & $0 \cdot 1 \mathrm{mg} / 1$ \\
\hline
\end{tabular}

* N'-2-Hydroxyethylpiperazine- $N$-2-ethanesulphonic acid.

$\dagger$ Nitroglycerin (Parke Davis, Edmonton, Alberta) was used in the perfusion buffer only.

$\ddagger$ Resazurin was used in the lumen buffers only.

to maintain vascular pressure, the tissue was flushed with heparinized $0.15 \mathrm{M}-\mathrm{NaCl}\left(38^{\circ}\right)$ while being clamped within the chamber. Usually 40-50 min elapsed between collection at the abattoir and the completion of the tissue mounting.

\section{Perfusion and chamber solutions}

Solutions used to perfuse or to bathe the lumen sides of the tissue were all freshly prepared; their compositions are given in Table 1 . The perfusate was equilibrated with $\mathrm{O}_{2}$-carbon dioxide $(95: 5, \mathrm{v} / \mathrm{v})$ at $38^{\circ}$ for at least $1 \mathrm{~h}$ before adjustment to $\mathrm{pH} 7.2$ and it was equilibrated continuously during use. The initial chamber solution was boiled for $5 \mathrm{~min}$ in order to reduce its $\mathrm{O}_{2}$ saturation and then maintained at $38^{\circ}$ until use. The chamber solution added later was made anaerobic by heating to $50-60^{\circ}$ for $30 \mathrm{~min}$ with continuous gassing by $\mathrm{O}_{2}$-free $\mathrm{N}_{2}$. The $\mathrm{O}_{2}$-free $\mathrm{N}_{2}$ was prepared by passing commercial $\mathrm{N}_{2}$ through a tubular furnace filled with reduced copper shavings at $350^{\circ}$. The solution was then brought to a boil for $3 \mathrm{~min}$ and a few crystals of sodium dithionite were added to remove the final traces of $\mathrm{O}_{2}$. This anaerobic chamber buffer was maintained at $50^{\circ}$ and continuously gassed with $\mathrm{O}_{2}$-free $\mathrm{N}_{2}$ until immediately before use. It was withdrawn into a glass syringe as needed from the stock solution and allowed to cool to $38^{\circ}$ before introduction into the lumen compartments or before use in preparation of rumen micro-organism and particle suspensions.

\section{Tissue perfusion}

A flow diagram of the tissue perfusion apparatus is presented in Fig. 1. Once the tissue was mounted in the chamber, the lumen compartments were filled with initial chamber solution and the arterial catheter was connected to the head of a positive displacement pump (Technicon Corporation, Montreal, Quebec). Perfusate was supplied at a rate of $1 \mathrm{ml} / \mathrm{min}$ for all experimental runs. The perfusion chamber was placed in a $38^{\circ}$ bath and, $2 \mathrm{~min}$ after the start of perfusion, the effluent was directed into a sample chamber of a polarographic $\mathrm{O}_{2}$ electrode (Model 53 Biological Oxygen Monitor; Yellow Springs Instrument Co., Yellow Springs, $\mathrm{OH}$ ). An extension of the venous catheter was inserted down the access groove of the plastic plunger which houses the electrode so that the effluent was delivered directly into the sample chamber for which the volume was maintained at less than $1.5 \mathrm{ml}$ to minimize response time. The effluent was thoroughly mixed in the sample chamber by a 


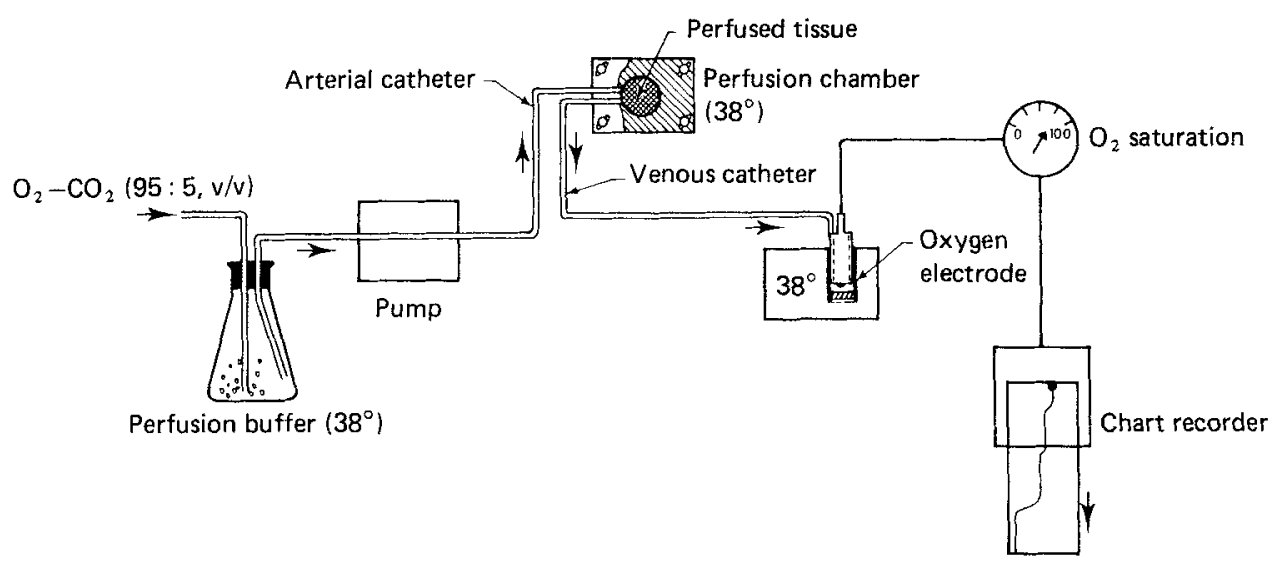

Fig. 1. System for perfusion and measurement of respiration of omasal laminae.

magnetic stirrer. Solution displaced from the chamber flowed from the access groove of the plunger and was removed by vacuum suction.

Baseline measurements of $\mathrm{O}_{2}$ saturation of fully-equilibrated perfusion buffer were obtained both before and after perfusion of the tissue while pumping through the same type, size and lengths of tubing used in the tissue perfusion and at the same rate of flow. Baseline saturation before perfusion of the tissue was set to $100 \%, \mathrm{O}_{2}$ saturation levels of perfusion buffer and effluent were recorded on a Honeywell 19 chart recorder. Changes in the recorded baseline saturation from before to after the perfusion, which were always small, were assumed to be linear over time.

\section{Lumen conditions during perfusion}

All additions to, or substitutions of, the solutions and suspensions within the lumen compartments were made after a period of at least 5 min during which the saturation of the perfusion effluent was stable.

Expt 1 . After the initial chamber buffer was drained and the lumen compartments were gassed with $\mathrm{O}_{2}$-free $\mathrm{N}_{2}$, anaerobic chamber buffer was injected into the lumen compartments. The anaerobic solution was then replaced by a heated preparation of rumen micro-organisms and small particles. This was subsequently replaced by an unheated portion of the same suspension.

The rumen micro-organisms and particle suspensions were prepared from rumen contents from a fistulated steer given a grass-hay diet. The contents were strained through four layers of cheesecloth and centrifuged in eight $35 \mathrm{ml}$ portions at $20000 \mathrm{~g}$ for $20 \mathrm{~min}\left(2^{\circ}\right)$. The sediment pellets were allocated to one of two equal groups (heated and unheated) and suspended in $22 \mathrm{ml}$ of the anaerobic-chamber buffer. One of the suspensions was heated in boiling water and maintained at $90^{\circ}$ for $10 \mathrm{~min}$, cooled to $38^{\circ}$ and introduced into the lumen compartments. The other suspension was prepared immediately before being used for replacement of the heated preparation.

Following a stable measurement of $\mathrm{O}_{2}$ saturation with the unheated micro-organism and particle suspension, butyrate and then propionate were added to the lumen buffer to final concentrations of $8 \mathrm{~mm}$-butyrate and then $8 \mathrm{~mm}$-butyrate plus $22 \mathrm{~mm}$-propionate. Butyrate

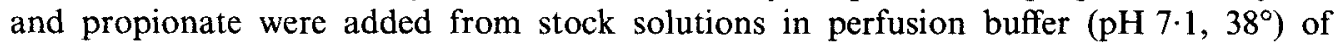
$160 \mathrm{~mm}$-sodium butyrate and $440 \mathrm{~mm}$-sodium propionate respectively.

The procedure for Expt 1 was repeated to yield complete results for six pieces of tissue, each being obtained from a different animal. 
Expt 2. The protocol for Expt 2 was similar to that for Expt $1 . \mathrm{O}_{2}$ saturation of the perfusate effluent was measured while the lumen side of the tissue was exposed to initial chamber buffer, $\mathrm{N}_{2}$ and then anaerobic-chamber buffer. After an $\mathrm{O}_{2}$ saturation measurement was obtained with anaerobic-chamber buffer, butyrate, then propionate and then DL3-hydroxybutyrate were added sequentially to the lumen compartments to final concentrations of $8 \mathrm{~mm}$-butyrate, $8 \mathrm{~mm}$-butyrate plus $22 \mathrm{~mm}$-propionate and $8 \mathrm{~mm}$-butyrate plus $22 \mathrm{~mm}$-propionate plus $8 \mathrm{mM}$-DL-3-hydroxybutyrate. The stock solutions used for addition were described previously for butyrate and propionate and for sodium DL-3-hydroxybutyrate the stock solution was $160 \mathrm{~mm}\left(\mathrm{pH} 7 \cdot 1,38^{\circ}\right)$.

Once a stable $\mathrm{O}_{2}$ saturation measurement was recorded for the anaerobic lumen buffer plus substrates, the mixture was removed from the lumen compartments and replaced by a heated suspension of washed rumen micro-organisms and particles plus substrates ( $8 \mathrm{~mm}$-butyrate plus $22 \mathrm{~mm}$-propionate plus $8 \mathrm{~mm}$-DL-3-hydroxybutyrate). The rumen micro-organism and particle suspensions used in Expt 2 differed from those used in Expt 1 in that, after the first centrifugation, each sediment pellet was suspended in $15 \mathrm{ml}$ of the anaerobic-chamber solution and centrifuged again. The resultant pellets were allocated to two groups and suspended in $22 \mathrm{ml}$ of the anaerobic-chamber buffer. One preparation was heated in boiling water and maintained at $90^{\circ}$ for $10 \mathrm{~min}$, cooled to $38^{\circ}$ and supplemented with butyrate, propionate and DL-3-hydroxybutyrate. The unheated suspension plus substrates was prepared immediately before being used to replace the heated suspension.

We obtained complete results from seven preparations of tissue, each taken from a different animal.

\section{Termination of the perfusion}

The volume of perfusate effluent collected over a 5 min period was used to calculate the rate of perfusate flow through the tissue and $\mathrm{O}_{2}$ saturation of the perfusion buffer was monitored. Before unclamping the tissue from the perfusion chamber, it was flushed with $1 \mathrm{ml} 150 \mathrm{~mm}$-Evan's Blue dye $(\mathrm{pH} \mathrm{7} \cdot 1)$ at the rate of $1 \mathrm{ml} / \mathrm{min}$ via the arterial catheter to show the actual area perfused during each trial. In all of the perfusions in this study, the dye was distributed over the entire circular area isolated by the inner ' $O$ ' ring. The stained area was dried to a constant weight at $80^{\circ}$ to determine the dry weight of the tissue that had been perfused.

\section{Electron microscopy samples}

In three of the seven trials of Expt 2, $4 \times 6 \mathrm{~mm}$ samples of the omasal leaves were taken for observation of the bacteria adhering to the mucosal wall of the tissue. Tissue samples were taken adjacent to the area to be perfused at the time the samples were collected at the abattoir and again immediately before clamping the tissue into the perfusion chamber (preperfusion). Postperfusion samples were obtained after the perfusion chamber was opened at the end of the trial; tissue to be sampled for electron microscopy was not infused with Evan's Blue dye and the area of postperfusion tissue taken was measured in order to estimate the total dry weight of perfused tissue. All sampled tissue was fixed with $50 \mathrm{ml}$ glutaraldehyde/litre $0.067 \mathrm{M}$-cacodylate buffer, $\mathrm{pH} 7 \cdot 2$, for $2 \mathrm{~h}$. The samples were subsequently washed twice in $0.067 \mathrm{M}$-cacodylate buffer, $\mathrm{pH} 7.2$, and then stored in the buffer at $4^{\circ}$. At $24 \mathrm{~h}$ before observation the samples were dehydrated in a graded series of ethanol washings, critical-point dried, gold-coated and mounted on observation stubs (McCowan et al. 1978). The samples were assessed for the presence of adherent bacteria using a Cambridge Stereoscan 180 scanning electron microscope which was operated at an accelerating voltage of $20 \mathrm{kV}$. 


\section{Calculations}

The rate $(\mathrm{nmol} / \mathrm{h})$ of tissue $\mathrm{O}_{2}$ uptake was calculated as:

$$
\left(S_{p^{-}}-S_{\varepsilon}\right) \times R \times 800 \mathrm{nmol} \mathrm{O}{ }_{2} / \mathrm{ml} \times 60 \mathrm{~min} / \mathrm{h},
$$

where $S_{p}$ represents the $\mathrm{O}_{2}$ saturation of perfusion buffer entering the tissue, $S_{e}$ is the $\mathrm{O}_{2}$ saturation of the effluent and $R$ is the rate of perfusate flow through the tissue. The $\mathrm{O}_{2}$ content of perfusion buffer that had been fully equilibrated with $\mathrm{O}_{2}-\mathrm{CO}_{2}(95: 5, \mathrm{v} / \mathrm{v}$ was considered to be $800 \mathrm{nmol} \mathrm{O}_{2} / \mathrm{ml}(20.3 \mu \mathrm{l} / \mathrm{ml})$ (Umbreit et al. 1964) since the atmospheric pressure in Edmonton is about $700 \mathrm{~mm} \mathrm{Hg}$ and the temperature of the buffer was $38^{\circ}$.

\section{Statistical analyses}

Since every piece of perfused tissue was obtained from a different animal, the results were analysed by two-way analysis of variance, with variation being ascribed to animals or to lumen conditions. When a significant $F$-value indicated differences between mean $\mathrm{O}_{2}$ uptake rates due to lumen conditions, the means were tested using the Duncan Multiple Range test (Steel \& Torrie, 1980).

\section{RESULTS}

$\mathrm{O}_{2}$ removal across perfused tissue

The first three conditions to which the lumen side of the tissue was exposed (initial solution, $\mathrm{N}_{2}$, anaerobic buffer) were used in both Expts 1 and 2. Mean $\mathrm{O}_{2}$ uptake rates during these conditions are presented in Tables 2 and 3. Fig. 2 is a diagramatic presentation of the recorded effluent saturations for Expts 1 (Fig. 2(a)) and 2 (Fig. 2(b)). The plots of effluent $\mathrm{O}_{2}$ saturation provide average values (Tables 2 and 3) for a perfused area of omasal leaf having a dry weight of $250 \mathrm{mg}$ with a perfusate flow of $1 \mathrm{ml} / \mathrm{min}$.

Replacement of the initial solution with $\mathrm{N}_{2}$ gas resulted in a $60 \%$ increase $(P<0.05)$ in $\mathrm{O}_{2}$ removal across the tissue in both experiments. Subsequent addition of the $\mathrm{N}_{2}$-equilibrated anaerobic solution restored the $\mathrm{O}_{2}$ uptake rates to those supported by the initial solution.

Expt $1 . \mathrm{O}_{2}$ consumption increased by $35 \%(P<0.01)$ when anaerobic buffer was replaced with the heated preparation of rumen micro-organisms and particles suspended in anaerobic buffer (Table 2). Substitution of unheated suspension for heated suspension did not result in a significant $(P>0.05)$ rise in the rate of $\mathrm{O}_{2}$ uptake. Finally, the addition of butyrate and then propionate to the unheated rumen suspension did not consistently increase the tissue $\mathrm{O}_{2}$ consumption.

Expt 2. Butyrate, when added to the anaerobic buffer, stimulated a $31 \%$ increase $(P<0.05)$ in the $\mathrm{O}_{2}$ uptake rate but the subsequent additions of propionate and DL-3-hydroxybutyrate had no additional effect (Table 3). An increase $(P<0.05)$ in $\mathrm{O}_{2}$ consumption did occur when the anaerobic buffer was replaced with the preparation of washed, heated rumen micro-organisms and particles plus substrates. Maximum consumption rates occurred with the unheated suspension of rumen micro-organisms and particles plus substrates. $\mathrm{O}_{2}$ uptake during exposure to the unheated suspension plus the added substrates was $12 \%$ greater $(P<0.05)$ than the rate measured with the heated suspension and $32 \%$ higher $(P<0.05)$ than the rate observed with anaerobic buffer plus substrates.

\section{Electron microscopy}

Scanning electron microscopy of the omasal leaf samples fixed at the abattoir, preperfusion and postperfusion, all revealed the presence of bacteria associated with the epithelium (Plate 1). The inspection of several sites per sample at a magnification of $\times 1500-2000$ 
Table 2. Expt $1^{*}$. Oxygen uptake rates of perfused bovine omasal laminae

(Means for six perfusions)

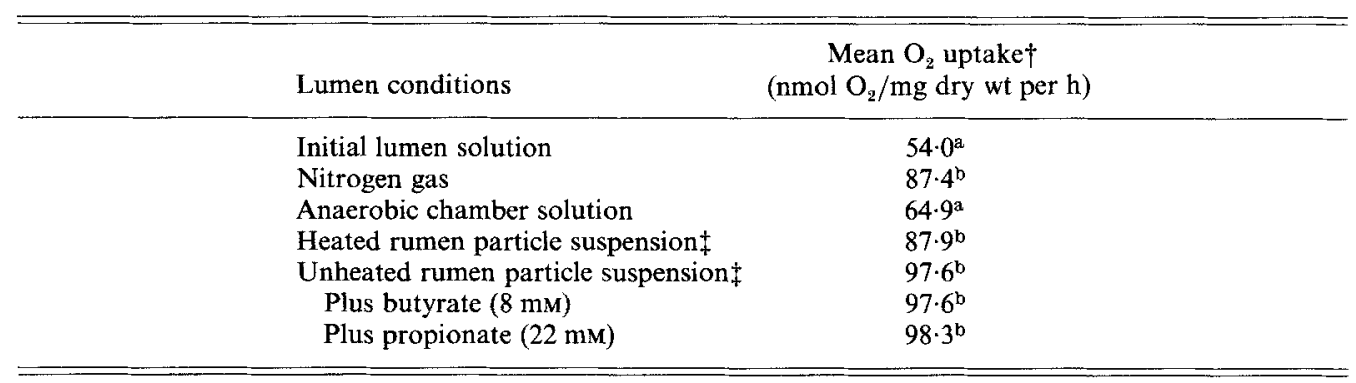

a, b Means with different superscript letters are significantly different $(P<0 \cdot 01)$.

* For details, see p. 314.

$\dagger$ Standard error $5.06 \mathrm{nmol} \mathrm{O}_{2} / \mathrm{mg}$ per h.

$\$$ Rumen particles $(<1 \mathrm{~mm})$ and micro-organisms suspended in anaerobic buffer.

Table 3. Expt 2*. Oxygen uptake rates of perfused bovine omasal laminae

(Means for seven perfusions)

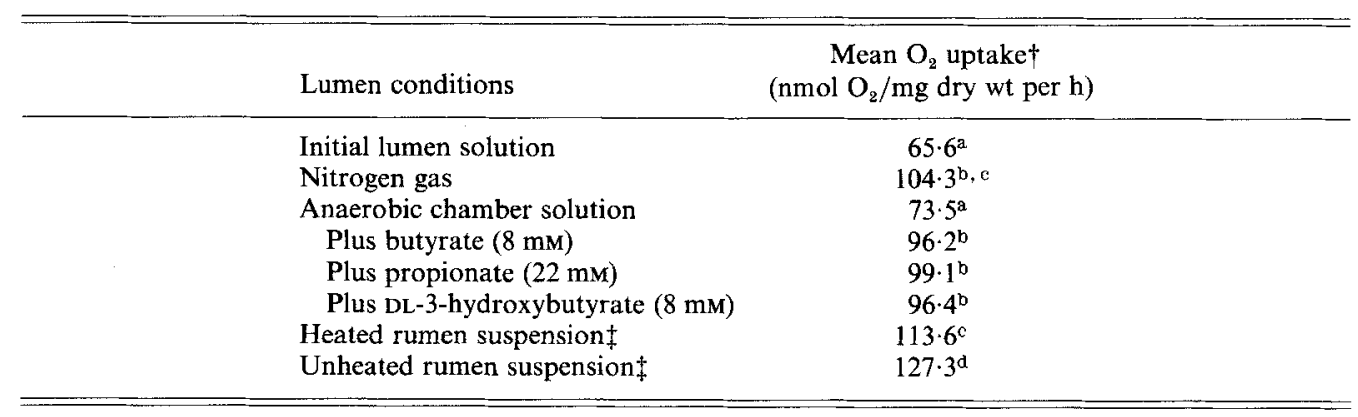

$\mathbf{a}, \mathbf{b}, c, d$ Means with different superscript letters are significantly different $(P<0.05)$.

* For details, see p. 315 .

$\dagger$ Standard error $3.82 \mathrm{nmol} \mathrm{O}_{2} / \mathrm{mg}$ per h.

$\ddagger$ Rumen particles $(<1 \mathrm{~mm})$ and micro-organisms suspended in anaerobic buffer with $8 \mathrm{~mm}$-butyrate, 22 mM-propionate and $8 \mathrm{~mm}$-DL-3-hydroxybutyrate.

indicated an overall coverage of $20-40 \%$ surface area of the tissue. In most cases, the bacteria were concentrated in microprotected areas of the tissue (Plates $1(b)$ and $(d)$ ), similar to the distribution observed by McCowan et al. 1980) and Mead \& Jones (1981) in the reticulo-rumen. The outlines of the keratinized epithelial cells are visible in Plate 1 . Several of the cells appeared to be sloughing off the surface of the epithelium. Colonies of bacteria adhering to the omasal laminae epithelium usually contained a mixture of morphological types (Plate $1(a)$ ). Such mixed bacterial colonies are also typical in the reticulo-rumen of cattle (McCowan et al. 1978, 1980). Bacteria associated with the epithelium were more prevalent on the tissue samples which were fixed at the abattoir, indicating that some of the bacteria were washed off during transport of the tissue. Mead \& Jones (1981) and Dehority \& Grubb (1981) demonstrated that most unattached bacteria and some adherent bacteria could be removed from the epithelium after two or three washings. Examination of the preperfusion and postperfusion samples did not reveal noticeable differences in bacterial coverage before and after perfusion. 

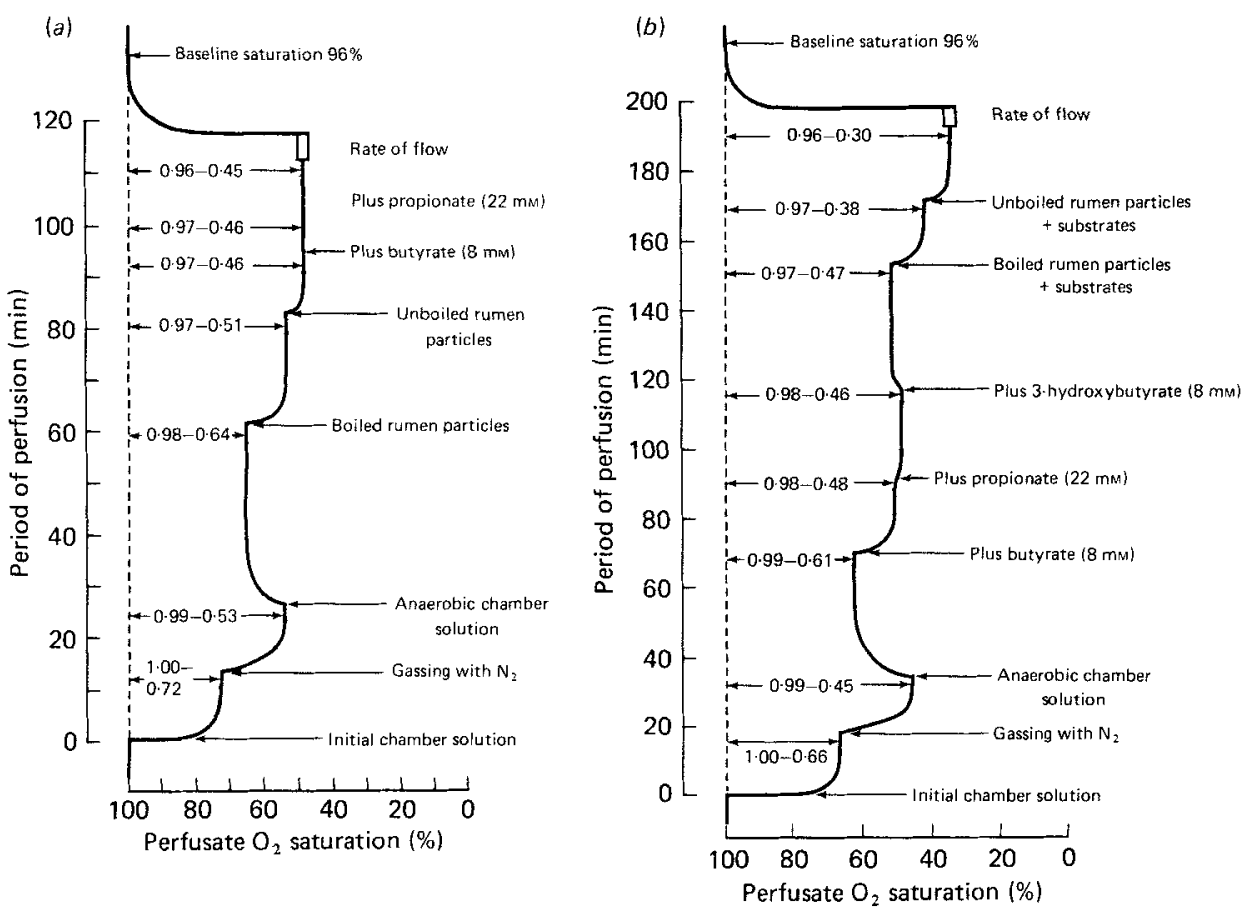

Fig. 2. Mean oxygen saturations of perfusates during (a) Expt 1 and $(b)$ Expt 2 (nominal tissue dry weight of $250 \mathrm{mg}$ and perfusion rate of $1 \mathrm{ml} / \mathrm{min}$ ). For details of Expts 1 and 2, see pp. 314-315.

\section{DISCUSSION}

Perfusion of an isolated area of bovine omasal laminae provided a physiologically-realistic method of investigating the influence of different lumen conditions on the $\mathrm{O}_{2}$ uptake of forestomach tissue. The even distribution of Evan's Blue dye throughout the area which was clamped within the perfusion chamber indicated the effective perfusion of the isolated area. In addition, the endogenous rates of $\mathrm{O}_{2}$ utilization $\left(\mathrm{O}_{2}\right.$ consumption in the presence of initial or anaerobic buffers) measured for the perfused areas of omasal leaves were similar to the endogenous rates $\left(60-120 \mathrm{nmol} \mathrm{O}_{2} / \mathrm{mg}\right.$ dry weight per $\mathrm{h}$ ) obtained for pieces of ovine omasal laminae incubated in Krebs-Ringer phosphate buffer (Hird \& Symons, 1959). Endogenous rates of $\mathrm{O}_{2}$ consumption ( $80-160 \mathrm{nmol} \mathrm{O} / \mathrm{mg}$ dry weight per $\mathrm{h}$ ) exhibited by incubated pieces of ovine and bovine rumen epithelium (Pennington, 1954; Hird et al. 1966; Goosen, 1976; Giesecke et al. 1979) are usually slightly higher than the rates measured with the perfused omasal leaves. If one assumes a capillary blood flow of $0.7 \mathrm{ml} / \mathrm{g}$ tissue per min in the omasal leaf (Engelhardt \& Hales, 1977) and an average arterio-venous $\mathrm{O}_{2}$ content difference (about $1.2 \mu \mathrm{mol} / \mathrm{ml}$ blood) across the omasum as for the rumen wall of sheep (Mathison, 1972), then the in vivo rate of $\mathrm{O}_{2}$ uptake of omasal leaves is calculated to be about $250 \mathrm{nmol} \mathrm{O}_{2} / \mathrm{mg}$ per $\mathrm{h}$ which is twice the maximum average rate observed for the perfused areas of the omasal laminae (Table 3). Therefore the values measured for the perfused preparation are not unreasonable.

The marked increase in $\mathrm{O}_{2}$ removal from the perfusate when the lumen chamber contained only $\mathrm{N}_{2}$ gas was unexpected. Perhaps the response to $\mathrm{N}_{2}$ entailed diffusion of $\mathrm{O}_{2}$ from the perfusate to the lumen surface of the epithelium since $\mathrm{N}_{2}$ should not have stimulated the respiratory activity of the tissue. The diffusion coefficient of $\mathrm{O}_{2}$ in $\mathrm{N}_{2}$ gas 
is ten thousand fold greater than in water (American Institute of Physics, 1972; Ramm, 1968). Therefore any $\mathrm{O}_{2}$ reaching the epithelial surface would diffuse away more quickly in a $\mathrm{N}_{2}$ atmosphere than in a buffer, thus creating a larger diffusion gradient with $\mathrm{N}_{2}$ than with either the initial or anaerobic lumen solution.

The possibility of diffusion of $\mathrm{O}_{2}$ into the lumen of the forestomach is not an entirely new concept. Although direct evidence of $\mathrm{O}_{2}$ diffusion into the rumen had not been presented, Czerkawski (1969) reasoned that the blood flow to the rumen wall was much larger than required for $\mathrm{O}_{2}$ delivery to support tissue respiration. On that basis, he estimated that as much as 35 litres $\mathrm{O}_{2} / \mathrm{d}$ could diffuse into the rumen of an adult sheep. Of course the movement of $\mathrm{O}_{2}$ across the tissue to the lumen will only be demonstrated unequivocally when $\mathrm{O}_{2}$ molecules from the perfusate can be identified on the lumen side of the tissue. In vivo observations at the surface of the rumen wall of a sheep given hay (Cheng \& Costerton, 1980) have revealed $\mathrm{O}_{2}$ contents of $10-20 \mathrm{ml} / \mathrm{l}$, which is higher than the content of 5-10 ml $\mathrm{O}_{2} / 1$ in rumen gas (McArthur \& Miltmore, 1961; Czerkawski \& Clapperton, 1968).

In preliminary trials, $10^{-3}$ to $10^{-2} \mathrm{M}$-sodium cyanide was added into the perfusate and into the rumen micro-organism and particle suspension in an attempt to abolish $\mathrm{O}_{2}$ uptake across the tissue. $\mathrm{NaCN}$ only abolished 0.8 of the $\mathrm{O}_{2}$ utilization in the presence of the suspension. The inability to abolish $\mathrm{O}_{2}$ uptake across the omasal tissue completely with $\mathrm{NaCN}$ could be due to one or more of several factors; perhaps cyanide was only partially effective in inhibiting respiration; perhaps the tissue or micro-organisms have some level of cyanide-insensitive respiration; or the remaining $\mathrm{O}_{2}$ removal may simply have been due to diffusion out of the tissue into the lumen compartments. The occurrence of cyanideinsensitive respiration cannot be overlooked, especially when the diversity of bacterial respiratory systems (Jurtshuk \& Yang, 1980; Knowles, 1980) is considered. Mixed species of rumen bacteria exhibit considerable NADH oxidase activity (Hobson \& Wallace, 1982), much of which may be insensitive to poisoning by cyanide. However, the possibility that bacterial cyanide-insensitive respiration contributed to the residual $\mathrm{O}_{2}$ upake would imply further that $\mathrm{O}_{2}$ was delivered to the lumen surface of the tissue.

The lack of respiration response to added butyrate in Expt 1 may have been due to the presence of high endogenous levels of the fatty acid already present with the particle suspensions. Respiration response to addition of butyrate to the anaerobic lumen buffer in Expt 2 is consistent with previous literature reports of increases of $30-80 \%$ in $\mathrm{O}_{2}$ uptake when butyrate was added to rumen epithelium incubated in vitro (Pennington, 1954; Goosen, 1976; Giesecke et al. 1979). Hird \& Symons (1959) reported an increase of $18 \%$ in the in vitro respiration of omasal laminae in response to $20 \mathrm{~mm}$-butyrate. An effect of provision of butyrate to substrate-depleted forestomach preparations on their respiration is logical in view of the suggestions that $85-90 \%$ of the butyrate absorbed from the ruminant forestomach is metabolized during absorption (Stevens, 1970; Bergman, 1975) largely by oxidation to ketone bodies (Hird \& Symons, 1959, 1961; Giesecke et al. 1979; Stangassinger et al. 1979), and in view of the large increases in rumen wall blood flow elicited when butyrate was added into the rumen (Sellers, 1965).

Evidence for significant propionate metabolism during absorption has also been reported (Stevens, 1970; Bergman, 1975; Weekes \& Webster, 1975), however this is not reflected in the in vitro oxidative metabolism of the forestomach epithelium upon provision of propionate as a substrate. Propionate usually does not increase $\mathrm{O}_{2}$ consumption above endogenous respiration of the tissue (Pennington, 1954; Goosen, 1976; Giesecke et al. 1979) and $\mathrm{O}_{2}$ consumption in the presence of butyrate is not stimulated by the addition of propionate (Goosen, 1976). Consistent with the in vitro results, we found that propionate had no significant effect $(P>0.05)$ on $\mathrm{O}_{2}$ utilization by omasal leaves supplied with butyrate. 
Addition of DL-3-hydroxybutyrate to the lumen solution containing $8 \mathrm{~mm}$-butyrate and 22 mm-propionate did not stimulate $\mathrm{O}_{2}$ removal across the tissue. $\mathrm{D}(-)$-3-Hydroxybutyrate dehydrogenase $(E C 1.1 .1 .30)$ is present in rumen epithelium (Koudakjian \& Snoswell, 1970; Watson \& Lindsay, 1972; Chandrasena et al. 1979) but it appears that there was either little activity in the direction of acetoacetate formation or, if there were oxidation, it was offset by decreased oxidation of another substrate or did not entail transfer of electrons to $\mathrm{O}_{2}$.

Despite being heated, the rumen micro-organism and particle suspensions consistently caused a significant increase in $\mathrm{O}_{2}$ uptake $(\mathrm{P}<0.05)$. The unwashed suspension (Expt 1$)$ stimulated a $35 \%$ increase over the rate of $\mathrm{O}_{2}$ uptake measured with the anaerobic buffer, while the washed suspension plus substrates (Expt 2) increased the $\mathrm{O}_{2}$ consumption rate by $18 \%$ over the rate measured with anaerobic buffer plus butyrate, propionate and 3-hydroxybutyrate. The former response, as inferred earlier, may have been confounded by provision of fatty acid substrates with the suspension, but the latter was not since these were already present. The nature of the heat-stable component(s) that stimulated respiration was not examined in the present study. However, Yamazaki \& Tove (1979) reported high concentrations of dithionite in cell-free extracts of Butyrivibrio fibrisolvens and that $0.2 \mathrm{ml}$ of cell-free extract would take up $138 \mathrm{nmol} \mathrm{O} / \mathrm{s}$. Hughes \& Tove (1980) suggested that dithionite may be a widespread constituent of microbes, particularly anaerobes. Butyrivibrio is a major genus isolated from sheep rumen epithelium (Dehority \& Grubb, 1981; Mead $\&$ Jones, 1981) and is significant in rumen digesta (Hungate, 1966). Therefore, it is tempting to speculate that dithionite in the heated microbe and particle suspensions may have contributed to their enhancement of $\mathrm{O}_{2}$ uptake across omasal leaves.

Since unheated microbial suspensions appeared to enhance $\mathrm{O}_{2}$ uptake across the omasal leaf to a greater extent than did heated preparations, there were likely organisms present that were able to utilize significant amounts of $\mathrm{O}_{2}$ derived from the perfusate after its movement out of the omasal tissue. There is evidence in the literature of uptake of $\mathrm{O}_{2}$ by rumen contents in vitro and in vivo (Baldwin \& Emery, 1960; Czerkawski \& Breckenridge, $1969,1979,1982$ ). Additionally, there are reports of $\mathrm{O}_{2}$ utilization by rumen micro-organisms, some of which may even have electron transport coupled to phosphorylation (Demeyer \& Van Nevel, 1975). The rumen protozoan, Dasytricha ruminatum, is able to survive $\mathrm{O}_{2}$ tensions of $2 \mathrm{kPa}$ and also exhibits respiration rates of $0.3-0.6 \mu \mathrm{mol} \mathrm{O} / 2 / \mathrm{min}$ per $10^{4}$ cells (Lloyd et al. 1982; Yarlett et al. 1982). Cheng \& Costerton (1980) reported that 25-50\% of the bacteria adhering to the rumen wall are facultative anaerobes and there has been contention (Wallace et al. 1979; Cheng et al. 1981) that they do indeed utilize $\mathrm{O}_{2}$ derived from the wall. Thus, suggestion of the use of $\mathrm{O}_{2}$ derived from the forestomach wall by microbes in the ruminant forestomach is not novel, nor is it unreasonable, but there has not previously been evidence as direct as that obtained in the present study to support the suggestion. The implications of this possibility are uncertain. Aerobic growth would be expected to increase microbial cell yields, but as yet the fate and metabolic value of $\mathrm{O}_{2}$ used by foregut microbes are not known (Baldwin \& Emery, 1960; Czerkawski \& Breckenridge, 1979, 1982).

The authors wish to thank Mr G. Braybrook (Department of Entomology, University of Alberta) for the scanning electron microscope preparations and Dr J. W. Czerkawski for comment on an early draft of the manuscript. Fresh omasal tissue was kindly provided by Gainers Ltd, Edmonton. This work was supported by a grant from the Natural Sciences and Engineering Research Council of Canada. A post-graduate scholarship (F.J.L.) from this same agency is also gratefully acknowledged. 


\section{REFERENCES}

American Institute of Physics (1972). American Institute of Physics Handbook [D. E. Gray, editor]. Toronto: McGraw-Hill Book Co.

Baldwin, R. L. \& Emery, R. S. (1960). Journal of Dairy Science 43, 506-511.

Bergman, E. N. (1975). In Digestion and Metabolism in the Ruminant, pp. 292-305. [I. W. McDonald and A. C. I. Warner, editors]. Armidale: University of New England Publishing Unit.

Chandrasena, L. G., Emmanuel, B., Hamar, D. W. \& Howard, B. B. (1979). Comparative Biochemistry and Physiology 64B, 109-112.

Cheng, K.-J. \& Costerton, J. W. (1980). In Digestive Physiology and Metabolism in Ruminants, pp. 227-250. [Y. Ruckebusch and P. Thivend, editors]. Lancaster: MTP Press.

Cheng, K.-J., Irvine, R. T. \& Costerton, J. W. (1981). Canadian Journal of Microbiology 27, 461-490.

Comline, R. S., Silver, R. A. \& Stevens, D. H. (1968). In Handbook of Physiology, Alimentary Canal, Sect. 6, pp. 2647-2671 [C.F. Code, editor]. Washington, DC: American Physiological Society.

Czerkawski, J. W. (1969). World Review of Nutrition and Dietetics 11, 240-282.

Czerkawski, J. W. \& Breckenridge, G. (1969). British Journal of Nutrition 23, 67-80.

Czerkawski, J. W. \& Breckenridge, G. (1979). British Journal of Nutrition 42, 229-245.

Czerkawski, J. W. \& Breckenridge, G. (1982). British Journal of Nutrition 47, 331-348.

Czerkawski, J. W. \& Clapperton, J. L. (1968). Laboratory Practice 17, 994-996.

Dehority, B. A. \& Grubb, J. A. (1981). Applied and Environmental Microbiology 41, 1424-1427.

Demeyer, D. I. \& Van Nevel, C. J. (1975). In Digestion and Metabolism in the Ruminant, pp. 366-382 [I. W. McDonald and A. C. I. Warner, editors]. Armidale: University of New England Publishing Unit.

Engelhardt, W. v. \& Hales, J. R. S. (1977). American Journal of Physiology 232, E53-E56.

Giesecke, D., Beck, E., Wiesmayr, S. \& Stangassinger, M. (1979). Comparative Biochemistry and Physiology 62B, 459. 463 .

Goosen, P. C. M. (1976). Zeitschrift für Tierphysiologie Tierernährung und Futtermittelkunde 37, 14-25.

Hird, F. J. R., Jackson, R. B. \& Weidemann, M. J. (1966). Biochemical Journal 98, 394-400.

Hird, F. J. R. \& Symons, R. H. (1959). Biochimica et Biophysica Acta 35, 422-434.

Hird, F. J. R. \& Symons, R. H. (1961). Biochimica et Biophysica Acta 46, 457-467.

Hird, F. J. R. \& Weidemann, M. J. (1964). Biochemical Journal 92, 585-589.

Hobson, P. N. \& Wallace, R. J. (1982). Critical Reviews in Microbiology 9, 253-320.

Hughes, P. E. \& Tove, S. B. (1980). Journal of Biological Chemistry 255, 4447-4452.

Hungate, R. E. (1966). The Rumen and its Microbes, 1st ed. New York: Academic Press.

Jurtshuk, D. \& Yang, I.-Y. (1980). In Diversity of Bacterial Respiratory Systems, vol. 1, pp. 137-159 [C. J. Knowles, editor]. Boca Raton: CRC Press, Inc.

Knowles, C. J. (editor) (1980). In Diversity of Bacterial Respiratory Systems, vol 2, pp. 139-158. Boca Raton: CRC Press, Inc.

Koudakjian, P. P. \& Snoswell, A. M. (1970). Biochemical Journal 119, 49-57.

Lloyd, D., Williams, J., Yarlett, N. \& Williams, A. G. (1982). Journal of General Microbiology 128, 1019-1022.

McArthur, J. M. \& Miltmore, J. E. (1961). Canadian Journal of Animal Science 41, 193-196.

McCowan, R. P., Cheng, K.-J., Bailey, C. B. M. \& Costerton, J. W. (1978). Applied and Environmental Microbiology 35, 149-155.

McCowan, R. P., Cheng, K.-J. \& Costerton, J. W. (1980). Applied and Environmental Microbiology 39, 233-241.

Mathison, G. W. (1972). Nitrogen metabolism in sheep. PhD Thesis, University of Alberta, Edmonton, Alberta.

Mead, L. J. \& Jones, G. A. (1981). Applied and Environmental Microbiology 41, 1020-1028.

Pennington, P. J. (1954). Biochemical Journal 56, 410-416.

Ramm, V. M. (1968). Absorption of Gases. Jerusalem: IPST Press.

Sellers, A. F. (1965). In Physiology of Digestion in the Ruminant, pp. 171-184. [R. W. Dougherty, editor]. Washington, DC: Butterworths Inc.

Stangassinger, M., Beck, V. \& Emmanuel, B. (1979). Annales de Recherches Veterinaires 10, 413-416.

Steel, R. G. D. \& Torrie, J. H. (1980). Principles and Procedures of Statistics. A Biometrical Approach, 2nd ed. Toronto: McGraw-Hill Book Co.

Stevens, C. E. (1970). In Physiology of Digestion and Metabolism in the Ruminant, pp. 101-112 [A. T. Phillipson, editor]. Newcastle upon Tyne: Oriel Press.

Umbreit, W. W., Burris, R. H. \& Stauffer, J. F. (1964). Manometric Techniques, 4th ed. Minneapolis: Burgess Publishing Co.

Wallace, R. J., Cheng, K.-J., Dinsdale, D. \& Ørskov, E. R. (1979). Nature 279, 424-426.

Watson, H. R. \& Lindsay, D. B. (1972). Biochemical Journal 128, 53-57.

Weekes, T. E. C. \& Webster, A. J. F. (1975). British Journal of Nutrition 33, 425-438.

Yamazaki, S. \& Tove, S. B. (1979). Journal of Biological Chemistry 254, 3812-3817.

Yarlett, N., Lloyd, D. \& Williams, A. G. (1982). Biochemical Journal 206, 259-266. 


\section{EXPLANATION OF PLATE}

Plate 1. (a) Scanning micrograph of bovine omasal lamina sample at the abattoir. Note the mixture of morphological types of bacteria adhering to the epithelium. Magnification $=\times 7900$. (b) Scanning micrograph of bovine omasal lamina sampled before perfusion. The small colony of bacteria appear to be in a cavity of the tissue surface, perhaps made when a distal epithelial cell sloughed off the surface. Magnification $=\times 4000$. (c) Scanning micrograph of bovine omasal lamina sampled before perfusion of the tissue. The outline of the epithelial cells is clearly visible. There is moderate coverage of bacteria adhering to the surface of the omasal epithelium. Note the epithelial cell lifting off the surface of the tissue (right side of the micrograph). Magnification $=\times 1600$. (d) Scanning micrograph of bovine omasal lamina sampled after perfusion. The outlines of the epithelial cells are clearly visible. The adherent bacteria are concentrated in a microprotected area of the surface (upper portion of the micrograph). Magnification $=\times 850$. 

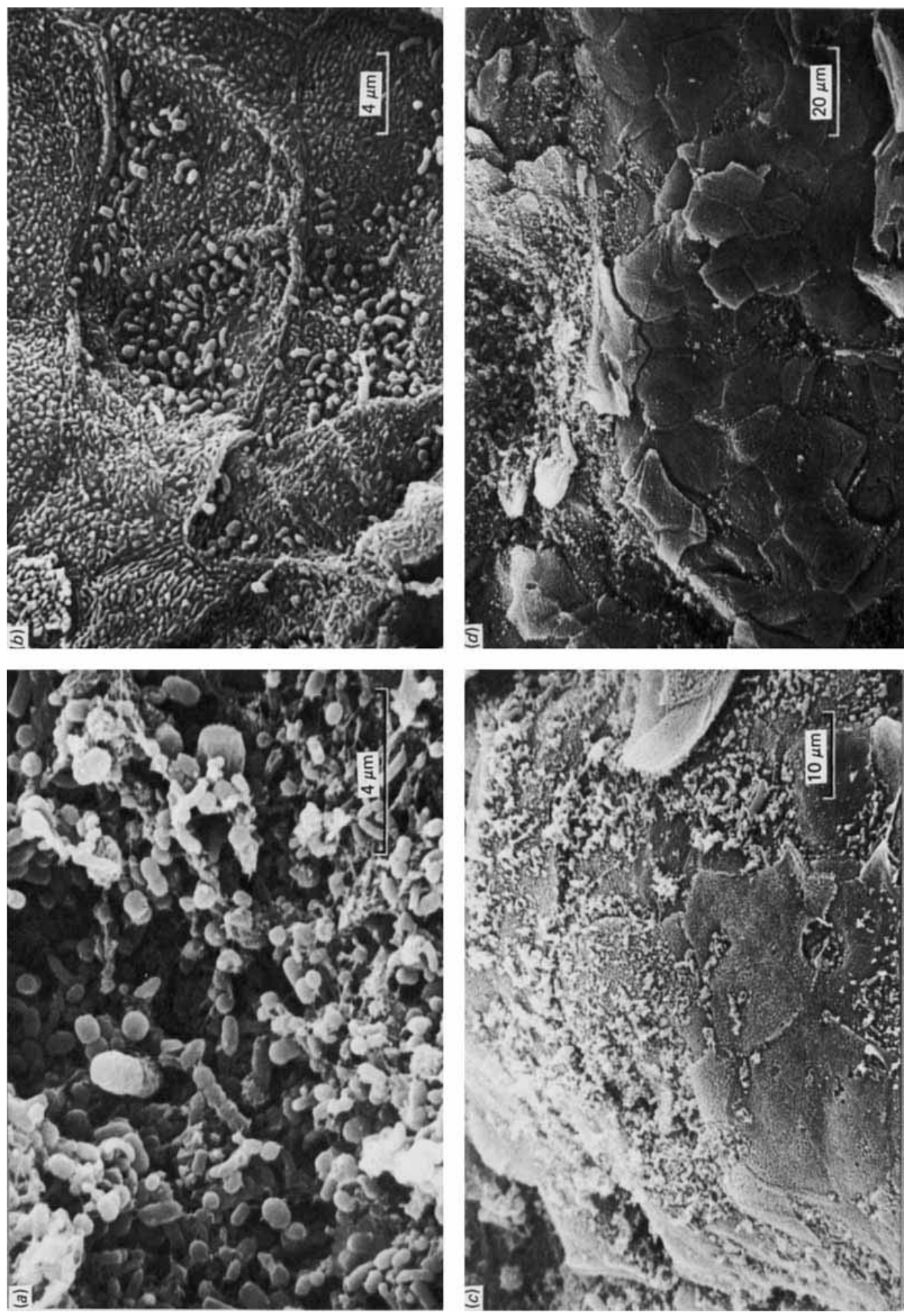